\title{
Foetal and placental metabolisms: their interrelationship and impact upon maternal metabolism*
}

\author{
By Frederick C. Battaglia and Giacomo Meschia, Division of Perinatal \\ Medicine, Departments of Pediatrics, Obstetrics-Gynecology and Physiology, \\ School of Medicine, University of Colorado Health Sciences Center, Denver, \\ Colorado
}

Since the publication of Kleiber's book, The Fire of Life ( $196 \mathrm{r}$ ), a comparative physiological approach to the metabolism of adult organisms has been strengthened considerably by demonstrating the close relationship of a large number of physiological variables to body-weight. Some of these metabolic variables include basal $\mathrm{O}_{2}$ consumption (Adolph, 1949; Kleiber, 1975; Zeuthen, 1953), glucose (Ballard et al. 1969) and lactate turnover rates (Freminet et al. 1972), fractional protein synthetic and turnover rates (Munro, 1969) and a variety of measurements which correlate with oxygen consumption such as heart rate and cardiac output (Adolph, 1967). While such relationships have been established for adult organisms, they have not been evaluated for foetal or neonatal life in any significant detail.

That such metabolic indices as glucose utilization rate should follow body size is surprising given the enormous diversity in diet of adult mammals from those living primarily on carbohydrate or protein to those on more mixed diets. The variability of diet among mammals is also impressive when considered against a background of the metabolic requirements of the conceptus. The bats, for example, vary in diet from the fruit eating bats living largely on carbohydrate to the vampire bats whose diet is almost entirely protein. Both produce newborns that may reach $30-40 \%$ of the maternal prepregnancy weight and must carry the pregnancy while flying and foraging for food. As Wimsatt (1969) has shown, the vampire bat adds to this an incredible feed-fast cycle, feeding for approximately $\mathrm{I}-2$ hours each day and fasting for the remainder. The metabolic demands of the conceptus upon the mother are such that the usual sexual dimorphism is reversed with the females larger than the males. Myers (1978) showed that the sexual dimorphism is related to the litter size, the larger the litter size the greater the difference in sexual dimorphism. Of course, the black bear is equally striking, the mother nourishing its conceptus while fasting and thirsting throughout the winter hibernation.

Table I gives some hint of why such metabolic indices as glucose turnover rates may follow adult body size despite the great variability in diet. It presents the glucose $/ \mathrm{O}_{2}$ quotients across the cerebral circulation in four different mammals. It is clear that regardless of the diet, the brain has a relatively high glucose requirement. Similar observations have been made for the metabolic profile across

-For reprints: Division of Perinatal Medicine, Box B-199, University of Colorado Health Sciences Center, 4200 East Ninth Avenue, Denver, Colorado 80262.

$0029-665^{1 / 81} / 4013^{-4802} \$ 01.00$ (c) 1981 The Nutrition Society 
Table 1. Cerebral glucose/oxygen quotients $\left(G / \mathrm{O}_{2}\right)$ in various species

\begin{tabular}{|c|c|c|}
\hline Species & $\mathrm{G} / \mathrm{O}_{2}$ & $\mathrm{G}-\mathrm{L} / \mathrm{O}_{2}$ \\
\hline \multicolumn{3}{|l|}{ Man: } \\
\hline Adult awake & 1.09 & $1 \cdot 00$ \\
\hline Adult awake + starved & 0.53 & 0.32 \\
\hline Children awake & $1 \cdot 5^{2}$ & 0.99 \\
\hline Infants anaesthetized & I. $4 \mathrm{I}$ & I 33 \\
\hline \multicolumn{3}{|l|}{ Sheep: } \\
\hline Adult awake & $1 \cdot 03$ & I. 00 \\
\hline Lamb awake & 0.99 & 0.96 \\
\hline Foetus unanaesthetized & 1.02 & 0.98 \\
\hline \multicolumn{3}{|l|}{ Rat: } \\
\hline Adult anaesthetized & $1 \cdot 83$ & $1 \cdot 66$ \\
\hline Infant anaesthetized & I. 82 & $1 \cdot 3^{8}$ \\
\hline \multicolumn{3}{|l|}{ Dog: } \\
\hline Newborn anaesthetized & $1 \cdot 17$ & $1 \cdot 10$ \\
\hline Adult anaesthetized & $1 \cdot 25$ & - \\
\hline
\end{tabular}

the coronary circulation and across the hind-limb or fore-limb. Fig. I taken from the study of Jarrett et al. (1976), presents the arterio-venous differences for acetate across the hind-limb of the adult sheep expressed as a percentage of $\mathrm{O}_{2}$ uptake. It should be pointed out that $80 \%$ of the energy requirements of sheep are met by short-chain fatty acids and $70 \%$ of this is acetate. It is clear that despite a large portal venous uptake of acetate it represents a comparatively small percentage of the energy requirements of skeletal muscle. In fact, even in sheep, as in man and other nonruminants the principal fuels for skeletal muscle are the long-chain fatty acids. Again species differences appear to be minimal despite comparisons of species which vary widely in dietary intake. It would appear that for those organs outside the GI tract the types of nutrients are rather similar among different species. From this it seems to us that there is no a priori reason to assume that the metabolic substrates required by the foetus of different mammals need necessarily be different.

\section{Foetal and placental $\mathrm{O}_{2}$ consumption}

The oxygen consumption of the mammalian foetus has been measured in several species. Some years ago, in preparing a review of foetal metabolism for Physiologic Reviews (Battaglia \& Meschia, 1978) Dr Meschia and I pointed out that the weight specific foetal oxygen consumption was remarkably similar in animals whose foetuses were very different in size, suggesting that the metabolic rate of the foetus may bear a different relationship to body size than is found in postnatal life. Table 2 provides the available information on foetal $\mathrm{O}_{2}$ consumption, and compares these with the oxygen consumption of the adult of the same species. The results for the rat are measurements made in newborns shortly after birth 


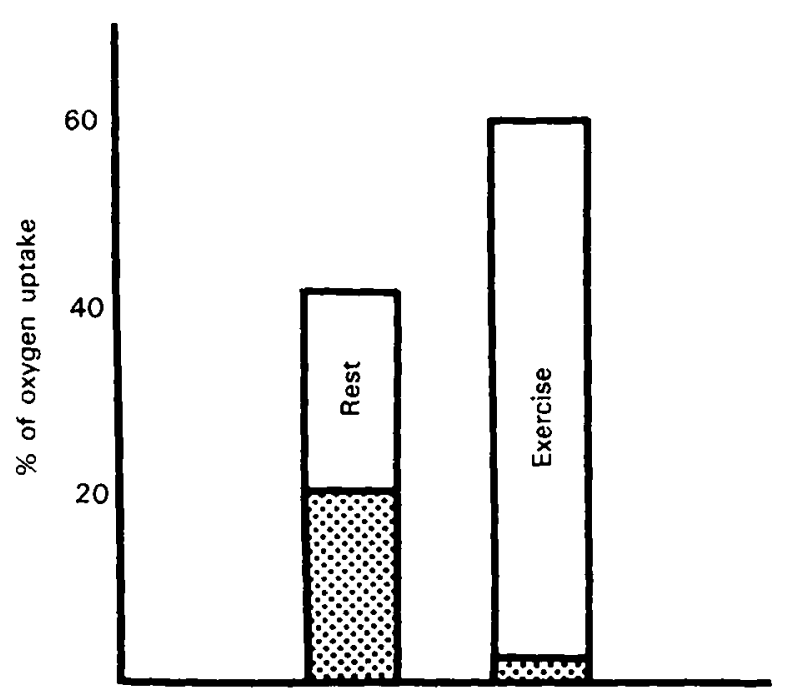

Fig. 1. The free fatty acid ( $\square$ ) and acetate (마) arterio-venous differences across the hindlimb of adult sheep during rest and exercise are presented as a percentage of oxygen uptake. The results are taken from the report by Jarrett et al. (1976).

(DeMeyer et al. 1971). We should like to pose the hypothesis that the weight specific foetal oxygen consumption will be less than the maternal in the small mammals and greater than the maternal in large mammals. This will be due to the fact that foetal $\mathrm{O}_{2}$ consumption will change less markedly with changes in body size than will the adult metabolic rate. In addition to the information presented in Table 2, several additional observations lend support to this hypothesis. Firstly, Moll has published the only observations estimating uterine $\mathrm{O}_{2}$ consumption in a smaller mammal (Moll et al. 1970). His estimate in the pregnant guinea-pig utilizing the Bohr principle is shown in Table 2 compared to the oxygen consumption of the rest of the maternal tissues. In the guinea-pig the uterine

Table 2. Foetal v. adult $\mathrm{O}_{2}$ consumption ( $\mathrm{ml} / \mathrm{min}$ per $\mathrm{kg}$ body-weight)

\begin{tabular}{lrc} 
& Adult & Foetal \\
Mare & 1.8 & 7.1 \\
Cow & 2.6 & 6.0 \\
Sheep and goat & 4.0 & 6.8 \\
Sheep & 4.0 & 7.5 \\
Monkey & 7.0 & 7.0 \\
Guinea-pig & 11.6 & 8.8 \\
Rat & 14.1 & $23.4 \dagger$ \\
\hline
\end{tabular}

-Represents uterine $\mathrm{O}_{2}$ consumption.

$\nmid 2 \mathrm{~d}$ after birth.

$\ddagger$ Newborn. 
oxygen consumption would represent a 'cold spot' relative to the rest of the mother. Since heart rate is related to the weight specific metabolic rate in adult life, Dr Paul Meiers in our laboratories has been attempting to measure the foetal heart rate in a small mammal, the guinea-pig, under chronic unstressed conditions. These studies have demonstrated that the foetal heart rate is lower than the maternal heart rate. Perhaps in part for similar reasons, the heart rate of the human foetus is only slightly higher at $10-12$ weeks gestation than it is at term despite a manyfold increase in body size. Considering the larger litter size in small mammals, the lower foetal $\mathrm{O}_{2}$ consumption compared to maternal tends to keep the oxygen consumption of all of the foetal mass as a relatively constant percentage of the maternal oxygen consumption. This is shown in Fig. 2 (Battaglia, 1980).

In recent years we have measured the uterine release and umbilical uptake of oxygen, glucose and lactate simultaneously during the latter part of gestation in pregnant sheep. Fig. 3 illustrates the oxygen and substrate flow to the foetus and placenta. The in vivo placental consumption rates of oxygen and glucose are very high, approximating those of brain tissue. The glucose utilization by a uteroplacental mass of approximately $700 \mathrm{~g}$ is approximately $36 \mathrm{mg} / \mathrm{min}$ or a rate of

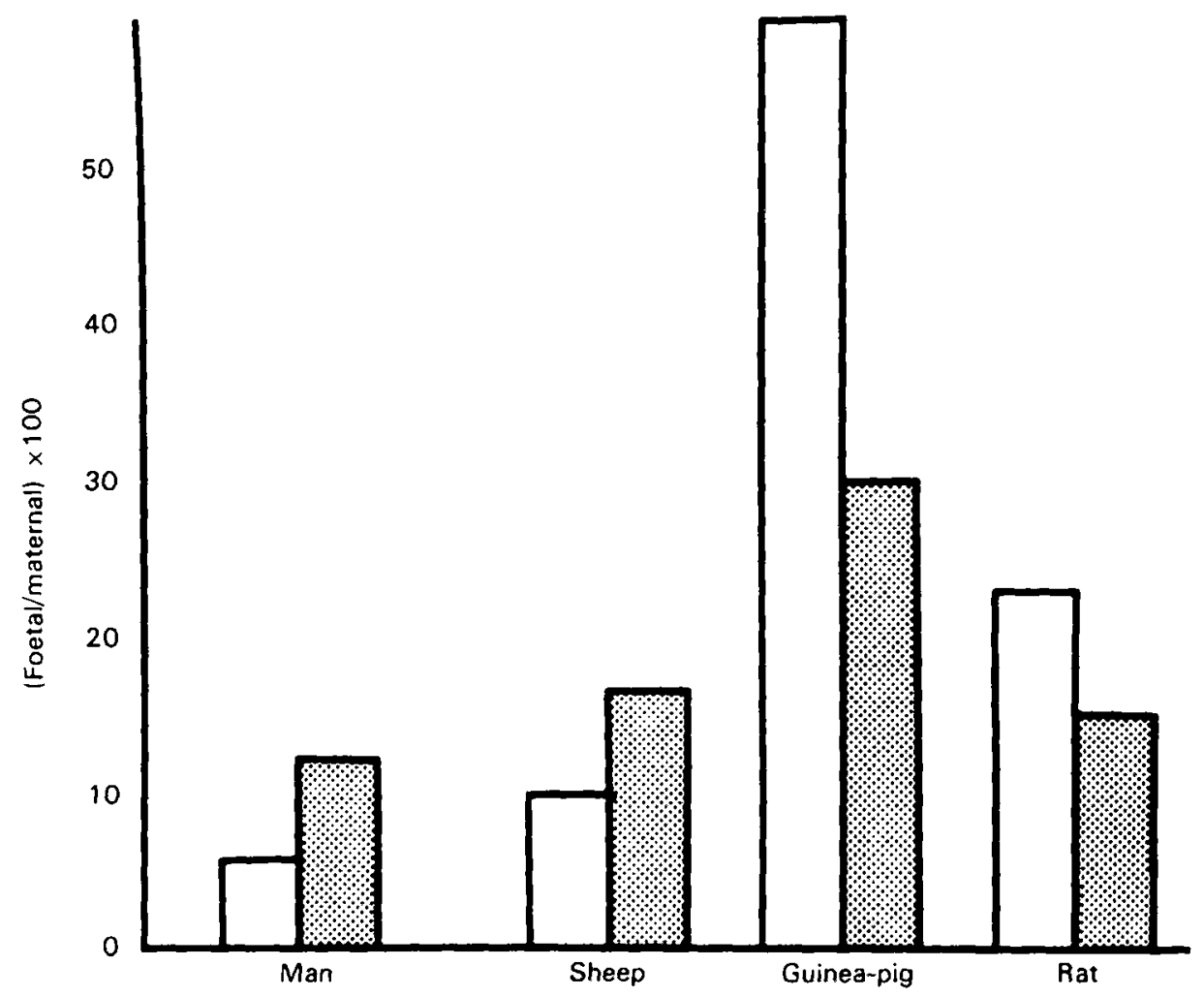

Fig. 2. The ratio of the total foetal weight as a percentage of maternal prepregnancy weight ( $\square$ ) and the total foetal $\mathrm{O}_{2}$ consumption as a percentage of maternal $\mathrm{O}_{2}$ consumption (司) for four species. The results are taken from Table I of Battaglia (1980). 


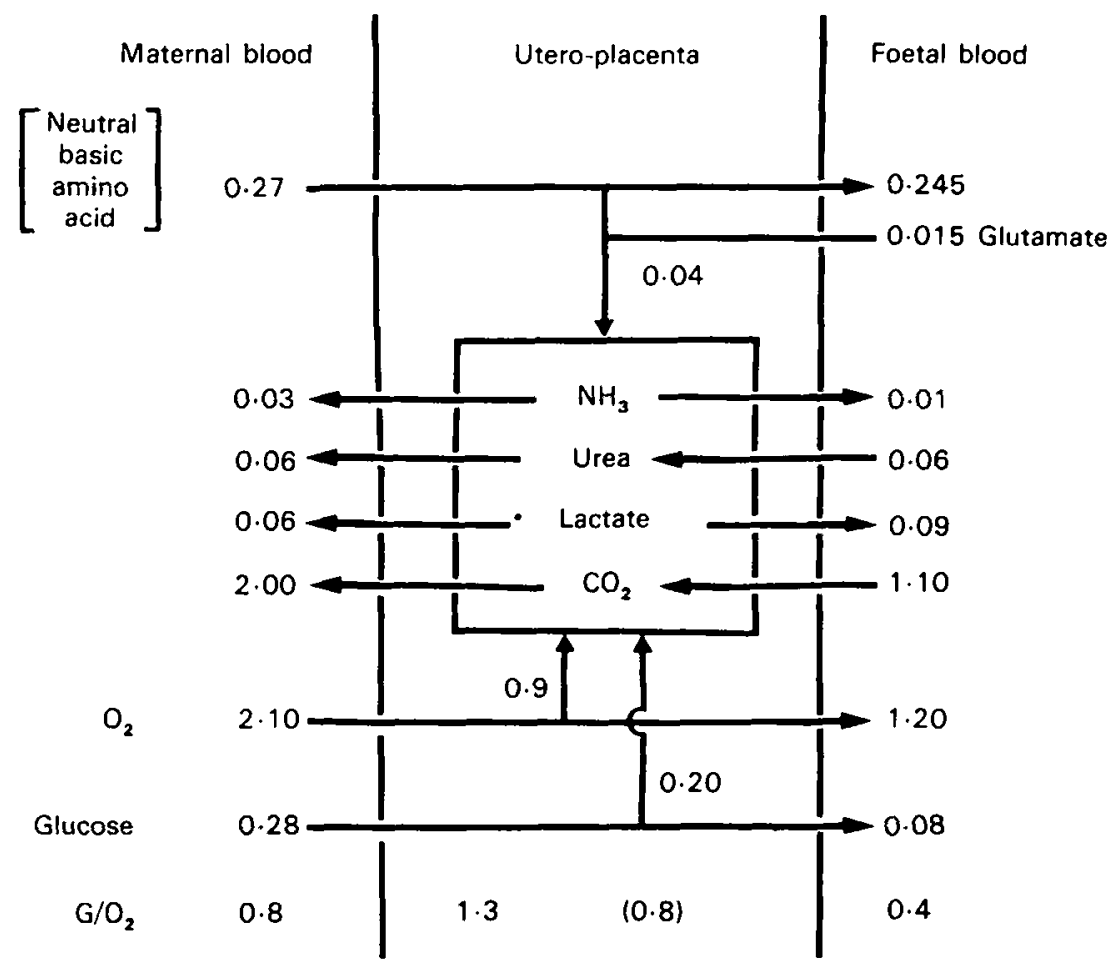

Fig. 3. A block diagram describing some of the measured fluxes of substrates into and out of the utero-placental unit of sheep during the latter $20 \%$ of gestation (amino acid fluxes in nitrogen millieq/min; all other fluxes in $\mathrm{mmol} / \mathrm{min}$ ). Relevant information for nitrogen exchange is shown in the upper part of the diagram and that for carbohydrate and oxygen exchange in the lower half of the diagram. Glucose/oxygen quotients are given as the glucose arterio-venous $(\mathrm{A}-\mathrm{V})$ differences across the uterine and umbilical circulations expressed in (mmol $\times 6) \div$ simultaneous $\mathrm{A}-\mathrm{V}$ difference for oxygen content. The glucose/oxygen quotient for the utero-placental unit is given as the measured value (i.e. $1 \cdot 3$ ) and also as the glucose/oxygen quotient after glucose utilization for the production of lactate has been subtracted (i.e. 0.8 ).

$50 \mathrm{mg} / \mathrm{kg}$ per min. Relative to weight this glucose utilization rate is approximately thirty-five times the maternal rate and ten times the foetal glucose consumption rate. Similarly, the weight specific placental oxygen consumption is almost five times the weight specific rate of oxygen utilization by the foetus. Thus, $50 \%$ of the oxygen and two-thirds of the glucose delivered by the maternal circulation to the uterus is consumed by the utero-placental tissue mass, with the remainder representing the umbilical uptake (Meschia et al. 1980). In sharp contrast, the uterine release of amino acids is approximately equal to the umbilical uptake (Holzman et al. I979). There is little net amino acid consumption by the uteroplacenta in late gestation.

\section{Glucose consumption}

At one time it was assumed that glucose was the sole fuel of the foetus. We will not try to review here the circumstantial evidence for this assumption. In the last 
ten years the glucose/oxygen quotient has been measured across the umbilical circulation in a number of different mammals including sheep, cows, horse and man. In all species the umbilical glucose/oxygen quotient is less than one (Battaglia \& Meschia, 1978). Umbilical uptake is reduced by the maternal hypoglycaemia which accompanies fasting. It is increased by either maternal hyperglycaemia or by foetal hyperinsulinaemia.

Changes in foetal glucose concentration do not necessarily imply parallel changes in placental glucose transport. This is an assumption often implicit in studies of 'accelerated starvation' of the mother carried out in small mammals. For example, the foetal hypoglycaemia which accompanies maternal fasting occurs with a low umbilical glucose uptake whereas the foetal hypoglycaemia produced by foetal insulin infusions is associated with.an increased umbilical glucose uptake and an increased foetal oxygen consumption (B. Quissell, D. Bonds, L. Krell, B. Carson, G. Meschia and F. C. Battaglia, unpublished results).

\section{Lactate metabolism}

Lactate concentrations are increased in the foetal circulation in all mammalian species in which it has been measured. Early investigators have interpreted this to reflect foetal hypoxia. Some years ago we demonstrated that the high foetal lactate concentration occurred in association with a net umbilical uptake of lactate (Burd et al. 1975). Thus, the foetus was a net lactate consumer. Recently, we have completed a more detailed analysis of lactate metabolism (J. W. Sparks, W. H. Glinsmann, M. A. Simmons, C. Horne and G. B. Avery, unpublished results). The estimates of lactate production within the foetus were made from infusions of $\left[{ }^{14} \mathrm{C}\right]$ lactate and tritiated glucose into the foetal circulation until steady state specific activities of glucose and lactate were achieved in the foetus. The large exogenous supply of lactate to the foetus ( $1.5 \mathrm{mg} / \mathrm{kg}$ per $\mathrm{min}$ ), represented by the umbilical uptake, is only one-quarter of the total lactate entry into the foetal lactate pool. The total lactate entry rate of $6 \mathrm{mg} / \mathrm{kg}$ per min represents $3.5 \mathrm{~g}$ carbon $/ \mathrm{kg}$ per $\mathrm{d}$. Excluding all excretory forms of $\mathrm{C}$ such as $\mathrm{CO}_{2}$, urea, etc., the accretion rate of $\mathrm{C}$ in the foetal lamb is $3.15 \mathrm{~g} \mathrm{C} / \mathrm{kg}$ per $\mathrm{d}$ of which approximately $2 \mathrm{~g}$ represents the $\mathrm{C}$ accretion in protein. The $\mathrm{C}$ accretion in the remainder of the foetal tissues is approximately $\mathrm{I} \cdot 2 \mathrm{~g} \mathrm{C} / \mathrm{kg}$ per $\mathrm{d}$. Thus, the lactate entry rate represents almost three times the non-protein $\mathrm{C}$ accretion rate in the foetus, defining, unambiguously, that lactate must be oxidized aerobically in the foetus.

\section{Amino acid metabolism}

At this time the quantities of amino acid taken up by the foetus have been measured in only one mammalian species, the foetal lamb (Lemons et al. 1976). Considering the importance of amino acids both for protein synthesis and as fuels for the foetus, this is somewhat surprising. In part, the paucity of studies reflects the methodologic problems involved in quantifying amino acid flow to tissues. The coefficient of extraction of amino acid across the umbilical circulation are in the order $8 \%$ and methods for quantifying amino acid concentrations in whole blood 


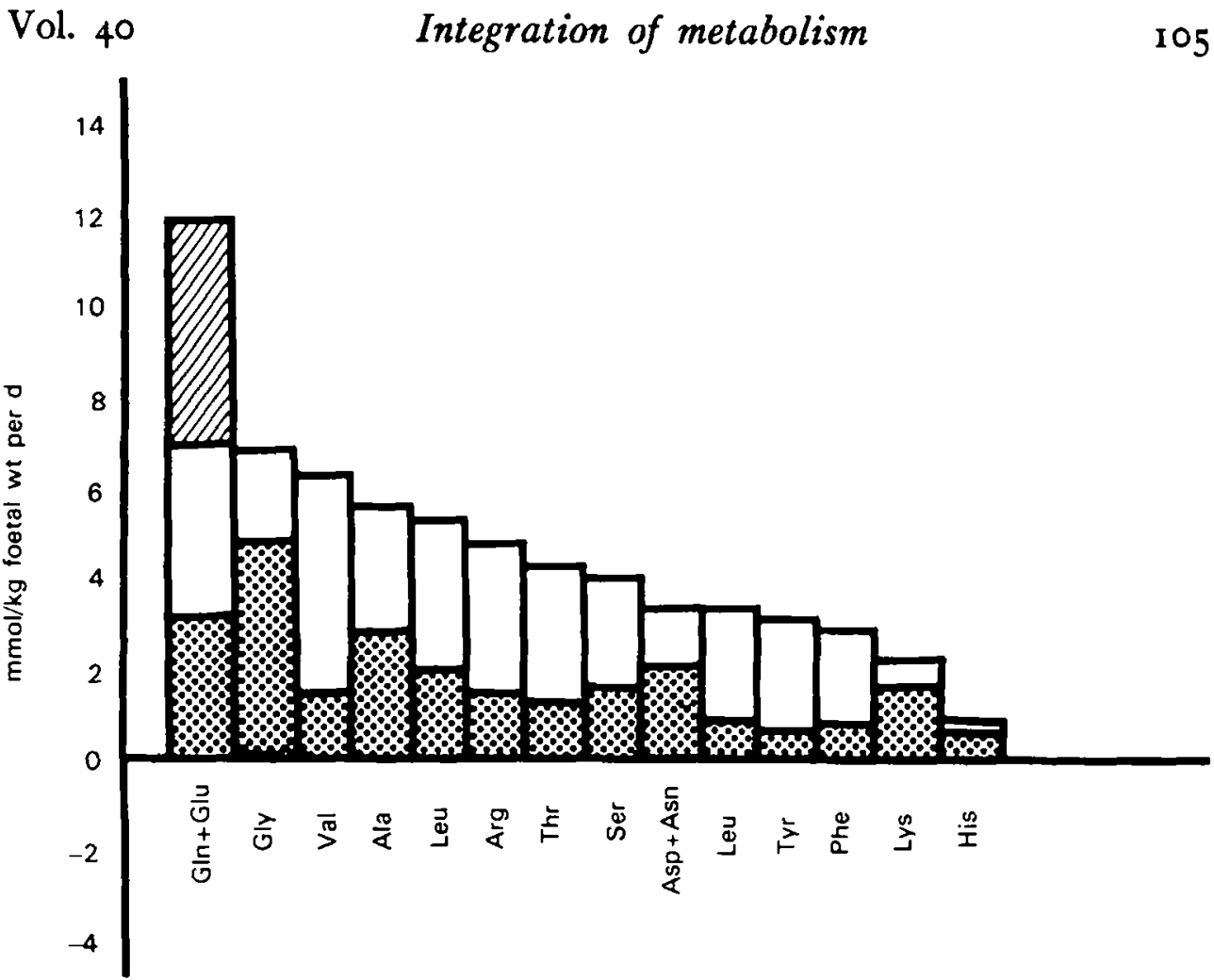

Fig. 4. The accretion of individual amino acids in the carcass of the foetal lamb during the latter

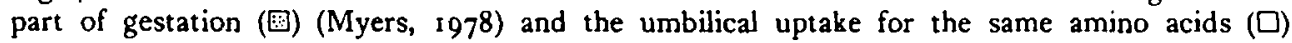
(Lemons et al. 1976). For glutamine and glutamate and for asparagine and aspartate the values shown for carcass accretion represent the total for both amino acids in each case since these cannot be distinguished after acid hydrolysis. For an algebraic sum of umbilical uptake in carcass

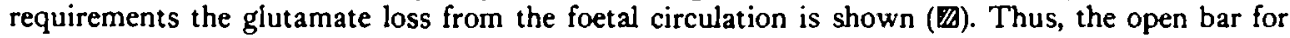
glutamine and glutamate represents the net excess of glutamine plus glutamate received by the umbilical circulation above that represented by carcass accretion and glutamate excretion.

have a variance of approximately $\pm 2 \%$. Thus, a very large number of arteriovenous $(\mathrm{A}-\mathrm{V})$ differences must be determined to arrive at an estimate of the mean $A-V$ difference across the umbilical circulation with any assurance. This methodologic problem of measuring relatively small $A-V$ differences almost precludes quantifying glycine uptake. Whole blood glycine concentration is very high, but its coefficient of extraction is quite low.

Originally we compared the umbilical uptake of individual amino acids with the accretion rate estimated from results of amino acid concentrations in whole body homogenates of three newborn calves. These were the only results in the literature. Recently we have completed the analysis of amino acid concentrations in the whole body homogenates of foetal lambs (P. Meier, G. Meschia, C. Teng and F. C. Battaglia, unpublished results). Fig. 4 presents the comparison of umbilical uptake with the accretion rate for each amino acid. It is clear that the neutral amino acids are delivered to the foetus in amounts which are in excess of their rates of accretion in foetal body proteins. The basic amino acids have a much smaller margin of 
safety in this respect since accretion represents approximately $75 \%$ of uptake, and the acidic amino acids must be synthesized in the foetus since there is no net umbilical uptake of this group. The maternal supply of amino acids has also been determined by a similar application of the Fick Principle. Fig. 5 presents a comparison of uterine to umbilical A-V differences for the individual amino acids (Holzman et al. 1979). The regression line shown has a slope of $\mathrm{I} \cdot 9$ in good agreement with published values for the ratios uterine:umbilical blood flows, implying that for most amino acids the quantities leaving the maternal circulation are approximately equal to that entering the umbilical circulation.

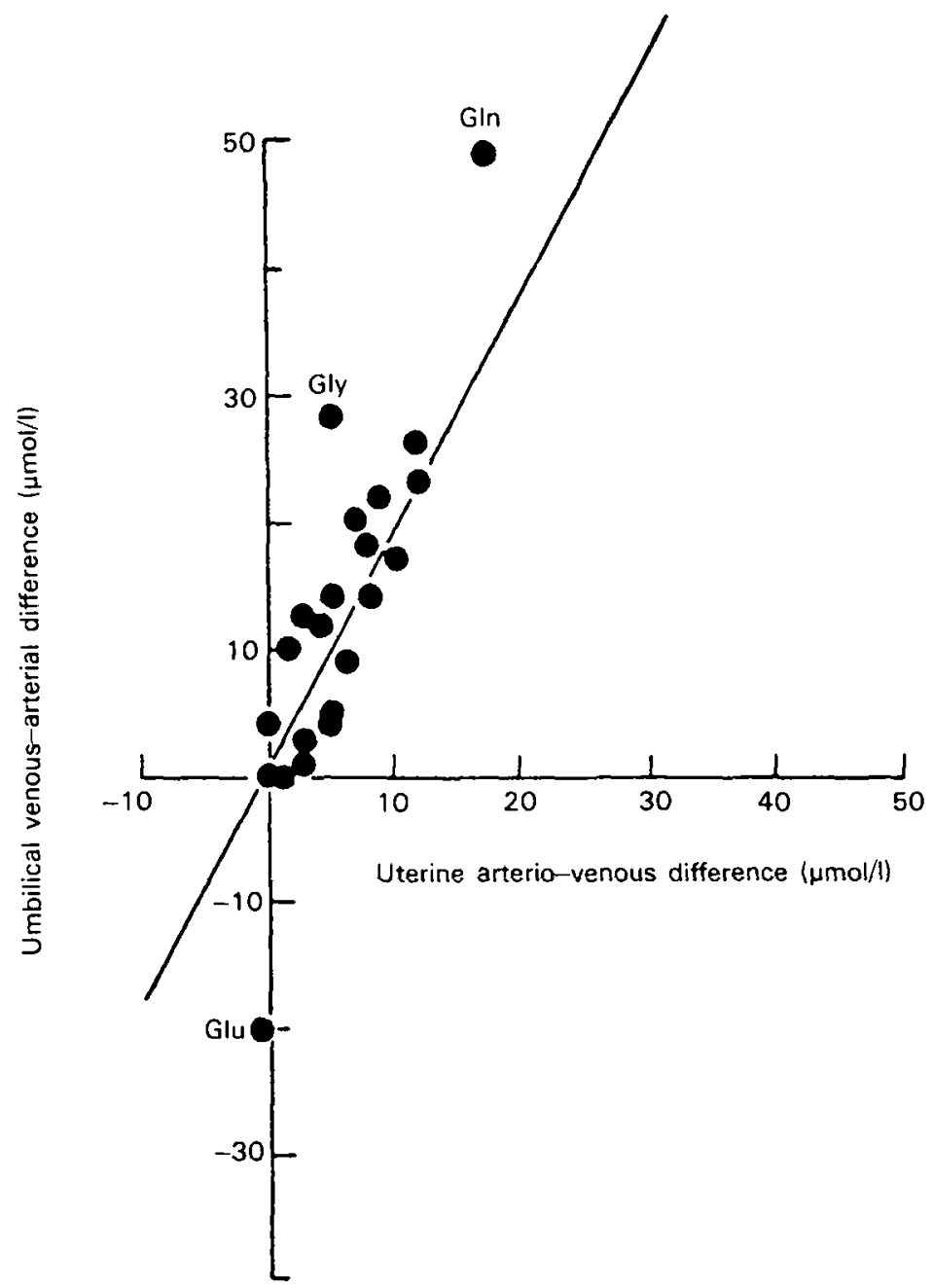

Fig. 5. Relationship of amino acid venous-arterial differences across the umbilical circulation to arterio-venous differences across the uterine circulation. The regression line includes all points with the exclusion of glycine, glutamine and glutamate (correlation coefficient $=0.85$ ) (Holzman et al. 1979). 
One question which remains to be fully answered in any single mammalian species is the magnitude of the substrate drain represented by the pregnant uterus upon the mother. In Fig. $6 \mathrm{I}$ have compared the arterio-venous differences for the two principal gluconeogenic amino acids, alanine and glutamine, across the hindlimb of adult sheep with that across the uterus. The values for hind-limb arteriovenous differences in both the fed and fasted states are taken from a report by Ballard et al. (1976) on nonpregnant adult sheep and those for the uterine uptake are results from our own laboratories (Holzman et al. 1979). Obviously, the quantities of alanine and glutamine taken up by the uterus and released by skeletal muscle are the products of these A-V differences multiplied by their respective blood flows. At term uterine blood flow is approximately $16 \%$ of cardiac output. The carcass blood flow in pregnant sheep has not been measured. However, the flow to the carcass plus gastrointestinal tract has been reported as approximately $60 \%$ of cardiac output (Rosenfeld et al. 1974). It would seem likely that at least $25 \%$ of this value represents skeletal muscle flow. Thus, Fig. 6 implies that the quantities of alanine and glutamine released from the muscle mass of the mother even in the fed state may be adequate to meet the requirements represented by the uterine uptake.

\section{A-V differences $(\mu \mathrm{M} / \mathrm{ml}$ blood $)$}

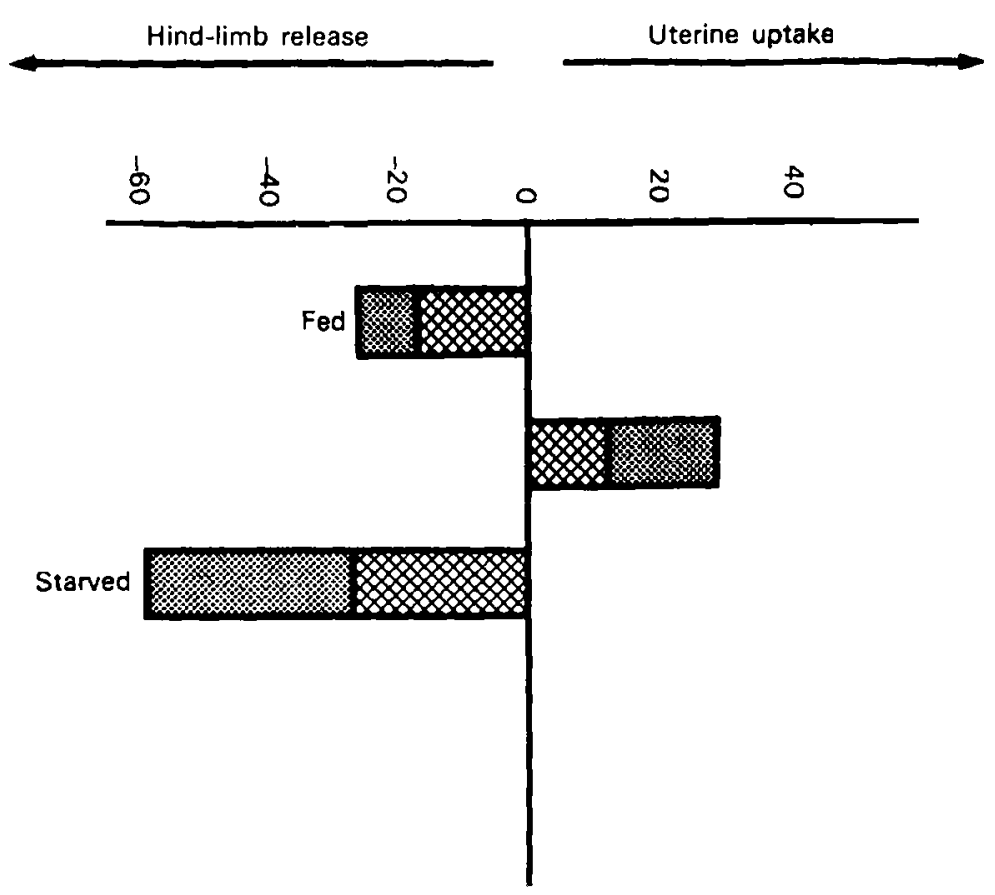

Fig. 6. A graph presenting the uterine uptake and hind-limb release of the two principal

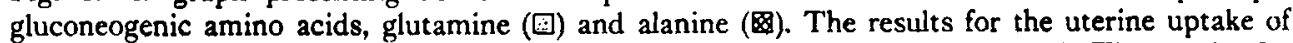
these amino acids in sheep are taken from the study of Holzman et al. (1979). The results for hind-limb release from adult sheep during fed and starved state are taken from the study of Ballard et al. (1976). 
As part of a systematic study of nitrogen balance in the ovine conceptus, we investigated the possibility that ammonia might represent an additional excretory form of $\mathrm{N}$ in addition to urea (Holzman et al. 1977). Fig. 7 demonstrates that the uterine V-A difference for ammonia expressed as a ratio of the oxygen $A-V$ difference is positive throughout gestation demonstrating a net efflux of ammonia from the uterus. There is a similar positive V-A difference for ammonia across the umbilical circulation which establishes that the utero-placental mass is the site of production of ammonia. The higher $\mathrm{V}-\mathrm{A}$ difference for ammonia in early gestation does not necessarily imply a higher rate of placental production since the uterine flow/g placenta is only approximately $0.5 \mathrm{ml} / \mathrm{min}$ per g placenta at $80 \mathrm{~d}$ gestation and increases to approximately $3 \mathrm{ml} / \mathrm{min}$ per g placenta at term, see Fig. 8 from Rosenfeld et al. (1974). The change in the V-A ammonia difference is about the same order of magnitude as the change in perfusion/g placenta suggesting that there may be approximately the same rate of production of ammonia per gram of placenta in early as in late gestation.

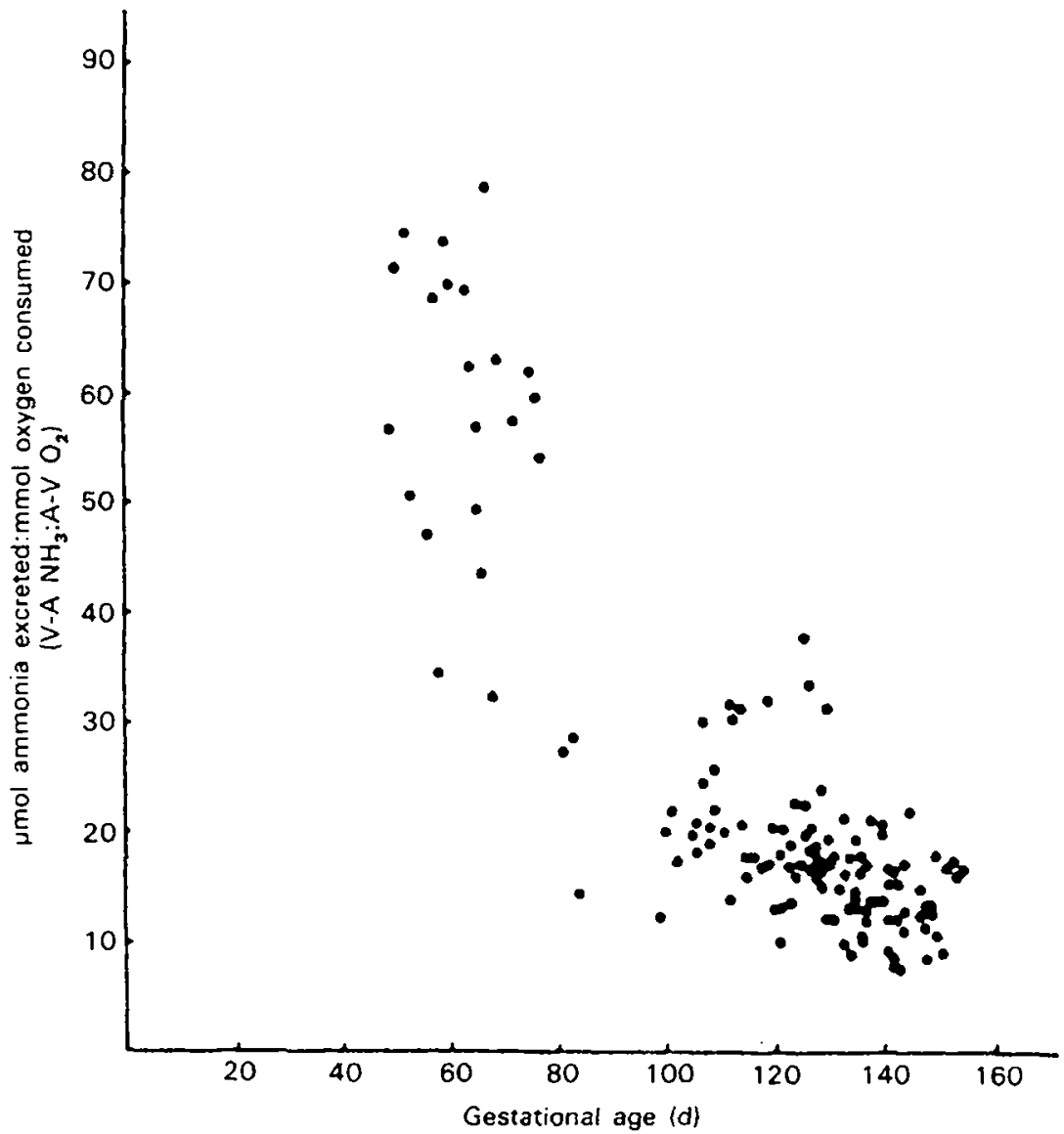

Fig. 7. A graph representing the ratio of ammonia ( $\mu$ mol) excreted into the maternal circulation: oxygen consumed (mmol) by the gravid sheep uterus from $47 \mathrm{~d}$ to term (Holzman et al. 1977). 


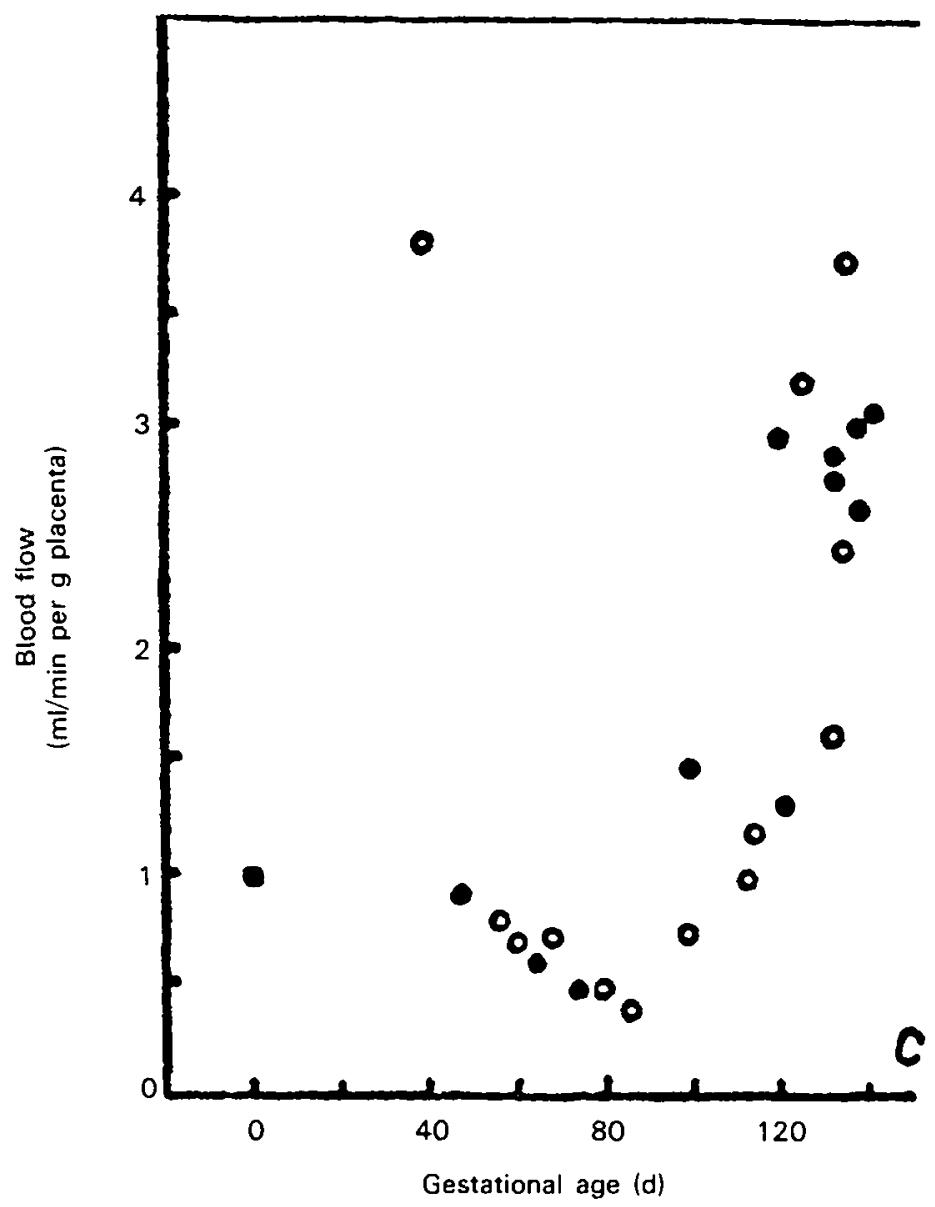

Fig. 8. Placental cotyledons. The observations on the nonpregnant animals represent weight and flow to the sites of implantation (caruncles) in oophorectomized ewes. The placental weight of twin gestation is the sum of the weights of two placentas. Likewise, placental blood fow of twin gestation is the sum of the placental flows of each twin. $(O)$, singleton gestation; $(O)$, twin gestation (Rosenfeld et al. 1974).

Thus, both ammonia and lactate share the characteristics of being produced in fairly large quantities by the placenta and delivered into both the uterine and umbilical circulations. Since both small molecules have been shown to alter the metabolism of isolated hepatocytes, one may speculate if their placental production provides a mechanism by which the placenta may regulate foetal hepatic metabolism.

\section{Comparative physiological studies}

Comparative physiological studies of foetal metabolism and of the impact of the conceptus upon maternal metabolism have been hampered by the fact that it has been possible to study animals under comparable conditions of biological steady 
state only in the large mammals, and even there, only in the latter $20 \%$ of gestation. Studies in small mammals such as rats and guinea-pigs have been performed under acute conditions making it difficult to determine whether the differences between these species and larger mammals reflected interspecies differences or differences in the biological states under which the studies were carried out. For these reasons we have made some efforts in recent years to establish a chronic animal preparation in the guinea-pig. Our reason for choosing this particular small mammal is that in a number of respects it seemed to provide an elegant counterfoil to study in the sheep. (I) It is a polytocous species with a median litter size of four permitting intralitter comparisons in metabolic studies; (2) the total mass of conceptus can equal $50 \%$ of the maternal prepregnancy weight representing a considerable metabolic drain upon the mother; (3) the foetuses contain a large amount of body fat at birth (10-12\%) in contrast to the sheep where the newborn lamb has a fat concentration of $\mathrm{I}-2 \%$. During a sabbatical year in Professor Jost's laboratory at the College de France I worked with several colleagues including Jean Girard to establish a chronic preparation in pregnant guinea-pigs which would permit studies in maternal metabolism. We have had some success in catheterizing the left ventricle and the femoral artery of the mother. The former catheter is used for the injection of radioactive microspheres and the latter for the withdrawal of a reference sample used in the calculation of cardiac output and individual organ blood flows including uterine flow. The same catheters can be used for substrate measurements and for infusions of radioactive glucose or other substrates for turnover measurements. These catheters have remained patent for varying periods of time up to four weeks post surgery.

The results I am presenting here are preliminary, but they do illustrate some of the potential of this preparation for chronic animal studies in a small mammal. Fig. 9(a) demonstrates the linear increase in both maternal weight and maternal food intake during pregnancy together with the foetal growth curve for a litter size of three. It brings out the enormous demands placed upon maternal metabolism in this species (J. W. Sparks, J.-P. Pegorier, J. Girard and F. C. Battaglia, unpublished results). The food intake had increased approximately $20 \mathrm{~g} / \mathrm{d}$ near term representing an increase in energy intake of $226 \mathrm{~kJ}(54 \mathrm{kcal}) / \mathrm{d}$. Each foetus in a litter of three increases its weight $3.5 \mathrm{~g} / \mathrm{d}$ for a total increase of foetal mass of I0. $5 \mathrm{~g} / \mathrm{d}$. If one assumes a content of $10 \%$ fat and $75 \%$ water for the new tissue, it would have an energy value of $6.3 \mathrm{~kJ}(1 \cdot 5 \mathrm{kcal}) / \mathrm{g}$ or a total energy accretion in the three foetuses of $65.9 \mathrm{~kJ}(15.7 \mathrm{kcal}) / \mathrm{d}$. From Moll's (1970) results, the oxidative metabolism of the pregnant uterus would account for another $10_{5} \mathrm{~kJ}(25 \mathrm{kcal}) / \mathrm{d}$. Thus, the total requirements for these two factors alone would equal approximately $168 \mathrm{~kJ}(40 \mathrm{kcal}) / \mathrm{d}$ or $80 \%$ of the increased energy intake. When we consider that the new tissue put down by the foetus is likely to have a fat concentration greater than $10 \%$, that the litter size often exceeds three, and that these calculations have not included alterations in maternal metabolism induced by pregnancy, there would appear to be scant reserves of energy intake in the 

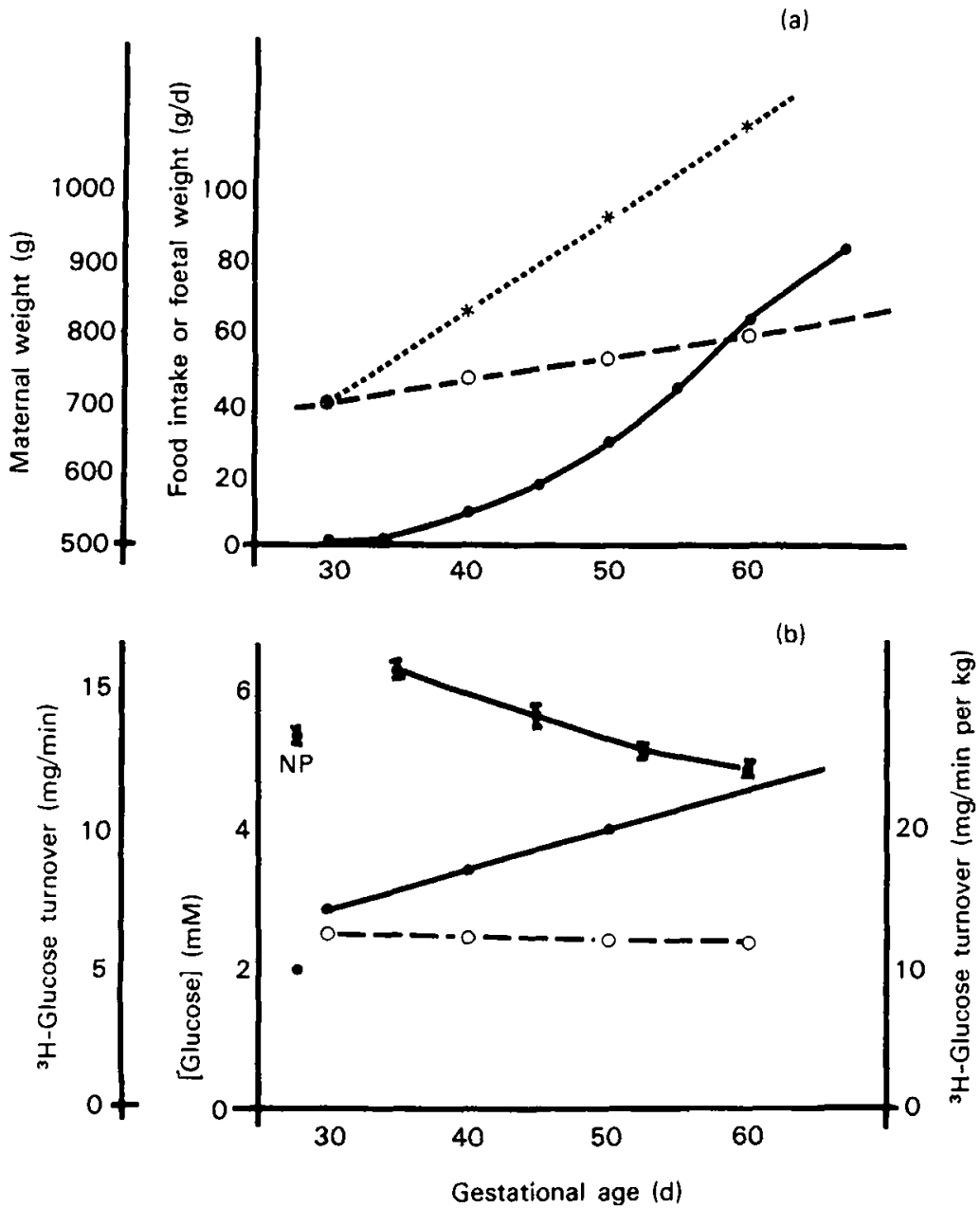

Fig. 9. (a) Maternal weight $\left({ }^{\bullet}\right)$ and food intake $(O)$ during pregnancy in the guinea-pig $(\mathrm{J} . \mathrm{W}$. Sparks, J.-P. Pegorier, J. Girard and F. C. Battaglia, unpublished results) and foetal weight (O), assuming a median litter size of three (Ibsen, 1928). (b) Glucose turnover rates (absolute, - (mg/min) and per unit maternal weight, $O$ ( $\mathrm{mg} / \mathrm{min}$ per $\mathrm{kg}$ maternal wt) (M. Gilbert, J. W. Sparks, J. Girard and F. C. Battaglia, unpublished results), and maternal glucose concentrations (O) (J. W. Sparks, J.-P. Pegorier, J. Girard and F. C. Battaglia, unpublished results).

pregnant guinea-pig during late gestation. Such calculations suggest a crucial role for the deposition and later mobilization of fat depots during pregnancy in this species.

Fig. 9(b) demonstrates the progressive fall in arterial glucose concentration during pregnancy in these animals studied under chronic steady state conditions. This was not demonstrable in animals studied under acute conditions. The progressive decrease in glucose concentration implies a new set point for glucose concentration in these ad lib.-fed pregnant animals, and it occurred in the face of a 
substantial increase in maternal food intake. Glucose turnover rate increased during pregnancy, but only in proportion to maternal weight gain (M. Gilbert, J. W. Sparks, J. Girard and F. C. Battaglia, unpublished results). This is somewhat surprising given the exponential increase in foetal size which may suggest that glucose utilization rate in the foetal guinea-pig, like oxygen consumption, may not have increased in the same proportion to its body size as it might in postnatal life.

\section{Summary}

In summary, foetal and placental metabolisms have certain characteristics which appear to bridge species differences. The consumption of carbohydrate and amino acids by the foetal lamb is adequate to meet the energy, $\mathrm{C}$ and $\mathrm{N}$ requirements of the foetus both for oxidated metabolism and for growth. Techniques to study foetal or maternal metabolism or both under conditions of a biological steady state, comparatively free of stress, are now readily available in several large mammals and are becoming so for small mammals. This should permit comparative physiologic studies in animals differing widely in diet and in body size. Hopefully, such studies will clarify those characteristics of foetal metabolism which are unique to a species and those which are common to all foetuses.

This work was supported by NIH Program Project Grant HD-oo78I and NIH Grant HD-or 866.

\section{REFERENCES}

Adolph, E. F. (1949). Science, N.Y. 109, 579.

Adolph, E. F. (1967). Am. J. Physiol. 21 2, 595.

Ballard, F. J., Filsell, O. H. \& Jarrett, I. G. (1976). Metabolism 25, 4 I 5.

Ballard, F. J., Hanson, R. W. \& Kronfeld, D. S. (I969). Fedn Proc. Fedn Am. Socs exp. Biol. 28, 2 I 8.

Battaglia, F. C. (1980). Proc. Samuel Z. Levine Conf. (In the Press).

Battaglia, F. C. \& Meschia, G. (1978). Physiol. Rer. 58, 499.

Burd, L. I., Jones, M. D. Jr, Simmons, M. A., Makowski, L., Meschia, G. \& Battaglia, F. C. (I 975). Nature, Lond. 254, 7 ro.

DeMeyer, R., Gerard, P. \& Verellen, G. (I971). In Metabolic Processes in the Fetus and Newborn Infant, p. $28 \mathrm{r}$. [J. H. P. Jonxis, H. K. A. Visser and J. A. Troelstra, editors]. Baltimore, Md.: Williams and Wilkins.

Freminet, A., Bursaux, E. \& Poyart, C. F. (1972). Pflugers Arch. 334, 293.

Holzman, I. R., Lemons, J. A., Meschia, G. \& Battaglia, F. C. (1977). Proc. Soc. exp. Biol. Med. I56, 27.

Holzman, I. R., Lemons, J. A., Meschia, G. \& Battaglia, F. C. (1979). Э. Der: Physiol. 1, I37.

Ibsen, H. L. (1928). F. exp. Zool. 51, 52.

Jarrett, I. G., Filsell, O. H. \& Ballard, F. J. (1976). Metabolism 25, 523.

Jones, M. D. Jr (1979). Semin. Perinatol. 3, 121.

Kleiber, M. (1961). The Fire of Life. New York: Wiley.

Kleiber, M. (1975). F. theor. Biol. 53, I 99.

Lemons, J. A., Adcock, E. W. III, Jones, M. D. Jr, Naughton, M. A., Meschia, G. \& Battaglia, F. C. ( 1976$)$. J. clin. Invest. $5^{8}, 1428$.

Meschia, G., Battaglia, F. C., Hay, W. W. \& Sparks, J. W. (1980). Fedn Proc. Fedn Am. Socs exp. Biol. 39, 245 .

Moll, W., Kunzel, W. \& Ross, H. G. (1970). Respir. Physiol. 8, 303.

Munro, H. N. (1969). Mammalian Protein Metabolism. New York: Academic Press. 
Vol. 40

Myers, P. (1978). Am. Nat. 112, 701 .

Rosenfeld, C. R., Morriss, F. H. Jr, Makowski, E. L., Meschia, G. \& Battaglia, F. C. (1974). Gynecol. Invest. 5, 252.

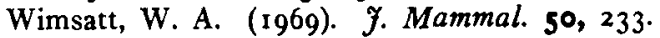

Zeuthen, E. (1953). Q. Rev. Biol. 28, I. 